\title{
PENGARUH SISTEM OLAH TANAH TERHADAP TOTAL BAKTERI TANAH PADA PERTANAMAN KEDELAI MUSIM TANAM KEDUA SETELAH PERTANAMAN JAGUNG DI LAHAN BEKAS ALANG-ALANG (Imperata cylindrica. L)
}

\author{
Ardy Mahendra Saragih, Dermiyati , Henrie Buchari \& M. A. Syamsul Arif \\ Jurusan Agroteknologi, Fakultas Pertanian Universitas Lampung \\ Jl. Prof.Soemantri Brodjonegoro No.1 Bandar Lampung 35145 \\ E-mail: ardymahendraaramaicsaragih@yahoo.com
}

\begin{abstract}
ABSTRAK
This study aims to determine the effect of tillage systems on Imperata grasslands are used as a soybean crop after the second growing season maize to total soil bacteria. The research this performed using by randomized block design (RBD) with three treatments tillage systems namely: TOT = No Tillage, OTM = Minimum Tillage, OTI = Intensive Tillage, with six replications. Soil samples were taken two weeks before tillage, one day after tillage, vegetative the maximum, and one day before harvest soybean plants. Soybean crop is used as an indicator of response to the treatment applied. The data obtained were tested homogeneity with Bartlett test and additivity tested by Tukey's test. Test the correlation between the main variables of total soil bacteria with supporting variable $\mathrm{pH}, \mathrm{C}$-organic, $\mathrm{N}$-total, temperature, and soil moisture. Data were analyzed by analysis of variance followed by LSD test $5 \%$. Tillage treatments were not significantly different to the total bacteria in the soil two weeks before the observation tillage, one day after tillage, vegetative period and the maximum one day before harvest soybean plants. There is a correlation between soil $\mathrm{pH}\left(\mathrm{H}_{2} \mathrm{O}\right)$ with total soil bacteria in the observation of one day before harvest soybean plants.
\end{abstract}

Keywords: Reeds, soybean, soil $\mathrm{pH}\left(\mathrm{H}_{2} \mathrm{O}\right)$, tillage systems, total soil bacteria.

\section{PENDAHULUAN}

Sektor pertanian merupakan bagian penting dalam pembangunan perekonomian di Indonesia pada umumnya, khususnya Provinsi Lampung. Hal ini dikarenakan kondisi alam dan luas areal lahan pertanian yang memadai untuk bercocok tanam. Salah satu upaya dalam meningkatkan dan mempertahankan ketahanan pangan adalah dengan melalui perluasan lahan pertanian. Lahan alang-alang merupakan lahan yang cukup potensial untuk pengembangan pertanian yang sejauh ini merupakan lahan terbuka yang dibiarkan dan belum dimanfaatkan. Penggunaan Sistem Olah Tanah Konservasi (OTK) dapat memperbaiki sifat fisik, kimia maupun biologi tanah, selain itu sifat biologi tanah penting yang menentukan baik atau tidaknya produktivitas lahan, yaitu keberadaan organisme tanah. Aktivitas pertanian seperti pengolahan tanah, pemupukan, dan aplikasi pestisida kimia dapat mempengaruhi kehidupan bakteri tanah.

Tujuan dari penelitian ini adalah untuk mengetahui pengaruh sistem olah tanah pada lahan alang-alang yang dimanfaatkan sebagai lahan pertanaman kedelai musim tanam kedua setelah pertanaman jagung terhadap total bakteri tanah.

\section{BAHAN DAN METODE}

Tempat dan Waktu. Penelitian ini dilaksanakan pada bulan Juli sampai dengan bulan November 2012 di lahan alang-alang desa Blora Kelurahan Segalamider, Tanjung Karang Barat.

Alat dan Bahan. Alat yang digunakan pada penelitian ini adalah plastik bening, gunting, isolasi, erlenmeyer, cawan petri, tabung reaksi, botol semprot, autoklaf, mikropipet, gelas ukur, mikroskop, corong, QCC (Quebec Colony Counter) dan alat-alat tulis. Bahanbahan yang digunakan adalah contoh tanah yang diambil dari setiap perlakuan yang diambil pada kedalaman 0$20 \mathrm{~cm}$. Bahan untuk analisis bakteri yaitu larutan fisiologis (8,5 $\mathrm{g} \mathrm{NaCl}$ dalam 1 liter aquades), media Nutrient Agar (NA) dan aquades.

Metode Penelitian. Penelitian ini dilakukan dengan menggunakan rancangan acak kelompok (RAK) dengan 6 ulangan. Terdapat tiga perlakuan yaitu: TOT $=$ Tanpa Olah Tanah, OTM = Olah Tanah Minimum dan OTI = Olah Tanah Intensif. 


\section{Pelaksanaan Penelitian}

Sejarah Lahan Penelitian. Lahan yang digunakan pada penelitian ini merupakan lahan alang-alang usia lebih dari 10 tahun. Selama 10 tahun, pengelolaan dilakukan hanya dengan memotong alang-alang setiap satu bulan sekali yang dibiarkan agar berdampak terhadap kandungan bahan organik tanah. Lahan tersebut tidak pernah dilakukan pengolahan tanah dan penanaman tanaman, hingga penelitian musim pertama pada tahun 2010. Setelah penelitian musim pertama, dilakukan pemberaan lahan selama satu tahun agar berdampak terhadap kandungan bahan organik tanah. Untuk menindaklanjuti hal tersebut dilakukan penelitian musim tanam kedua dengan menggunakan tanaman kedelai.

Pengambilan Sampel di Lapangan. Contoh tanah diambil sebanyak lima titik setiap ulangan, sampai kedalaman $20 \mathrm{~cm}$. Kemudian pada setiap titik dikompositkan berdasarkan ulangan. Pengambilan sampel awal dilakukan dua minggu sebelum pengolahan tanah, pengambilan sampel tanah kedua setelah satu hari pengolahan tanah, pengambilan sampel ketiga pada masa vegetatif maksimum (64 HST), dan pengambilan sampel keempat (99 HST) dilakukan satu hari sebelum panen tanaman kedelai.

Tata Laksana Penelitian. Pembuatan plot percobaan dilakukan 2 minggu sebelum pelaksanaan penelitian. Plot percobaan dibuat secara kelompok dengan enam kelompok dan tiga perlakuan olah tanah. Pada perlakuan OTI, pengolahan tanah dimulai dengan pembabatan alang-alang, kemudian tanah diolah sebanyak 2 kali. Untuk perlakuan OTM, lahan tidak disemprot menggunakan herbisida tetapi hanya dilakukan pembabatan gulma dan pengolahan tanah seperlunya yaitu hanya sedalam $10 \mathrm{~cm}$. Pada perlakuan TOT, lahan disemprot menggunakan herbisida Round Up yang berbahan aktif Glifosat dengan dosis 4 liter ha ${ }^{-1}$ untuk menghilangkan gulma yang tumbuh, dan kemudian gulma dibiarkan dan digunakan sebagai mulsa. Pupuk diberikan secara tugal dikiri-kanan lubang tugalan benih, dengan jarak 10-15 cm di samping tanaman selanjutnya ditutup kembali dengan tanah. Penyiangan gulma pertama dilakukan dua minggu setelah tanam dan penyiangan selanjutnya dilakukan 2 minggu kemudian, penyulaman dilakukan pada waktu tanaman berumur 1 minggu melalui sulam benih. Untuk mencegah hama dan penyakit dilakukan penyemprotan pestisida yang memiliki bahan aktif fipronil dengan konsentrasi $4 \mathrm{ml} \mathrm{liter}^{-1}$ air.

\section{Variabel Pengamatan}

Variabel Utama. Variabel utama yang diamati adalah total populasi bakteri tanah. Untuk menghitung total populasi bakteri tanah menggunakan metode cawan agar. Metode hitungan cawan didasarkan pada anggapan bahwa setiap sel yang dapat hidup akan berkembang menjadi satu koloni. Jadi jumlah koloni yang muncul pada cawan merupakan suatu indeks bagi organisme yang dapat hidup yang terkandung dalam sampel. Pengukuran jumlah bakteri dilakukan dengan menggunakan metode cawan agar dengan teknik sebagai berikut.

Pembuatan Seri Pengenceran. Pembuatan seri pengenceran dilakukan dengan memodifikasi (Arif et al., 2009). Pembuatan larutan fisiologis $(8,5 \mathrm{~g} \mathrm{NaCl}$ dalam 1 liter aquades). Larutan fisiologis sebanyak $9 \mathrm{ml}$ dimasukkan ke dalam Erlenmeyer serta tabung reaksi sebanyak 7 buah. Tabung reaksi dan Erlenmeyer ditutup dengan kapas dan alumunium foil, selanjutnya tabung reaksi dan Erlenmeyer yang berisi larutan fisiologis diautoklaf selama 20 menit pada temperatur $121^{\circ} \mathrm{C}$. Setelah itu didinginkan pada suhu $42-45{ }^{\circ} \mathrm{C}$ sebelum digunakan. Untuk mendapatkan larutan $10^{-1}$, dilakukan dengan memasukkan $10 \mathrm{~g}$ tanah yang telah diayak ke dalam $90 \mathrm{ml}$ larutan fisiologis steril dan dikocok dengan menggunakan vorter secara perlahan-lahan. Kemudian $1 \mathrm{ml}$ larutan pengenceran $10^{-1}$ dimasukkan ke dalam tabung reaksi yang berisi $9 \mathrm{ml}$ larutan fisiologis dengan menggunakan pipet sehingga diperoleh seri pengenceran $10^{-2}$ dan seterusnya hingga diperoleh seri pengenceran $10^{-8}$.

Pembuatan Media Bakteri. Media biakan bakteri yang digunakan untuk mengidentifikasi bakteri tanah yaitu media Nutrient Agar. Kemudian disterilkan dengan menggunakan autoklaf selama 20 menit, setelah itu media didiamkan pada temperatur sekitar $45^{\circ} \mathrm{C}$ ( Anas, 1989).

Pengamatan Bakteri. Pengamatan dilakukan setelah hari ke 3 setelah inkubasi. Menghitung jumlah koloni yang muncul pada tiap kali pengamatan. Bila dilihat dari warna, elevasi, (cembung, rata, cekung), pinggiran koloni (bergerigi, mulus, berhifa). Untuk memudahkan penghitungan pada cawan petri dapat digunakan Quebec Colony Counter. Untuk menghitung jumlah mikroorganisme dari sampel tanah yang dihitung adalah dengan mengalikan rata-rata jumlah koloni dengan faktor pengencer. 


\section{CFU s ml-1 $($ sampel tanah $)=$ rata-rata koloni per cawan $\mathrm{x}$ faktor pengencer}

Hasil ini kemudian dikonversi ke jumlah mikroorganisme dalam 1 gram tanah kering mutlak dengan memperhitungkan kadar air tanah.

Variabel Pendukung. Variabel pendukung yang diamati adalah: (1) pH tanah, dengan metode elektrometik, (2). $\mathrm{C}$-organik tanah (\%) dengan menggunakan metode Walkley and Black, (3). N-total (\%) dengan menggunakan metode Kjeldahl, (4) Suhu tanah $\left({ }^{\circ} \mathrm{C}\right)$, (5) Kelembapan tanah (\%), (6) Kadar air tanah (\%). Uji korelasi antara variabel utama (total bakteri) dengan variabel pendukung $\mathrm{pH}$ tanah, $\mathrm{C}$-organik (\%), N-total $(\%)$, suhu tanah $\left({ }^{\circ} \mathrm{C}\right)$, dan kelembapan tanah $(\%)$.

\section{HASIL DAN PEMBAHASAN}

\section{Pembahasan}

Perlakuan olah tanah tidak berbeda nyata terhadap total bakteri tanah (Tabel 1) dan uji BNT 5\% (Tabel 2) pada pengamatan dua minggu sebelum olah tanah, satu hari setelah olah tanah, masa vegetatif maksimum maupun masa satu hari sebelum panen tanaman kedelai. Hal ini diduga, belum adanya pengaruh tiap perlakuan olah tanah baik tanpa olah tanah (TOT), olah tanah minimum (OTM) maupun olah tanah intensif (OTI) akibat pemberaan selama satu tahun setelah penelitian sebelumnya memberikan akumulasi bahan organik yang seragam terhadap perlakuan olah tanah. Walaupun perlakuan olah tanah berbeda, total bakteri tanah belum menunjukkan perbedaan tiap perlakuan olah tanah karena lambatnya proses dekomposisi bahan organik oleh mikroorganisme yang terjadi di dalam tanah sehingga menghasilkan sedikit ketersediaan sumber energi dan nutrisi untuk aktivitas mikroba tanah.

Selain itu, hal ini diduga kondisi lingkungan yang ada pada lahan tersebut masih cukup terjaga dengan baik sehingga menciptakan iklim mikro yang tidak berbeda dari berbagai pengolahan tanah. Penyiraman yang dilakukan setiap hari satu kali pada sore hari menyebabkan keseragaman suhu dan kelembapan,

Tabel 1. Ringkasan analisis ragam pengaruh perlakuan olah tanah pada lahan alang-alang terhadap total bakteri tanah yang ditanami kedelai.

\begin{tabular}{ccccc}
\hline \multirow{2}{*}{$\begin{array}{c}\text { Variabel } \\
\text { Pengamatan }\end{array}$} & 2 SOT & 1HSPT & $\begin{array}{c}\text { Vegetatif Maksimum } \\
\text { (64 HST) }\end{array}$ & $\begin{array}{c}\text { Panen } \\
\text { (99 HST) }\end{array}$ \\
\cline { 2 - 5 } & tn & tn & tn & tn \\
\hline Total Bakteri & tn & thengamatan & .
\end{tabular}

Keterangan: th = tidak berbeda nyata; 2 SOT = dua minggu sebelum olah tanah;1HSPT =satu hari setelah pengolahan tanah; HST = Hari Setelah Tanam.

Tabel 2. Uji BNT $5 \%$ pengaruh perlakuan olah tanah pada lahan alang-alang terhadap total bakteri tanah yang ditanami kedelai

\begin{tabular}{lcccc}
\hline \multirow{2}{*}{ Perlakuan } & \multicolumn{4}{c}{ Waktu Pengamatan } \\
\cline { 2 - 5 } & 2 SOT & 1 HSPT & $\begin{array}{c}\text { Vegetatif Maksimum } \\
\text { (64 HST) }\end{array}$ & $\begin{array}{c}\text { Panen } \\
\text { (99 HST) }\end{array}$ \\
\cline { 2 - 5 } & \multicolumn{4}{c}{ Total bakteri tanah $($ log CFU g-1 tanah) } \\
\hline TOT & $7,29 \pm 0,1 \mathrm{a}$ & $7,19 \pm 0,1 \mathrm{a}$ & $7,33 \pm 0,1 \mathrm{a}$ & $7,31 \pm 0,1 \mathrm{a}$ \\
OTM & $7,30 \pm 0,0 \mathrm{a}$ & $7,20 \pm 0,0 \mathrm{a}$ & $7,31 \pm 0,1 \mathrm{a}$ & $7,28 \pm 0,0 \mathrm{a}$ \\
OTI & $7,28 \pm 0,1 \mathrm{a}$ & $7,20 \pm 0,1 \mathrm{a}$ & $7,29 \pm 0,1 \mathrm{a}$ & $7,27 \pm 0,0 \mathrm{a}$ \\
BNT 5\% & 0,01 & 0,01 & 0,02 & 0,02 \\
\hline
\end{tabular}

Keterangan: TOT $=$ Tanpa Olah Tanah; OTM = Olah Tanah Minimum; OTI = Olah Tanah Intensif; 2 SOT = dua minggu sebelum olah tanah;1HSPT =satu hari setelah pengolahan tanah; HST = Hari Setelah Tanam. Angka yang di ikuti huruf yang sama menunjukkan tidak berbeda antar perlakuan. 
sehingga pengaruh sistem olah tanah tidak berbeda nyata terhadap total bakteri tanah. Dengan demikian, maka total bakteri tanah memberikan hasil yang sama untuk setiap perlakuan olah tanah.

Perlakuan olah tanah terhadap total bakteri tanah (Gambar 1) menunjukkan pada pengamatan sebelum olah tanah ke masa satu hari setelah olah tanah mengalami penurunan. Hal ini diduga, perlakuan olah tanah dapat mengubah sifat fisik, kimia dan biologi tanah. Perubahan struktur tanah karena pengolahan tanah dapat menurunkan diversitas populasi bakteri lebih tinggi di daerah yang jauh dari perakaran sehingga mempengaruhi proses-proses di rizosfir.

Perlakuan olah tanah terhadap total bakteri tanah pada pengamatan satu hari olah tanah ke masa vegetatif maksimum, mengalami peningkatan. Total bakteri tanah tertinggi teramati pada perlakuan tanpa olah tanah (TOT) diikuti dengan olah tanah minimum (OTM) dan olah tanah intensif (OTI). Hal ini di duga, pada perlakuan (TOT) tanah tidak diolah dan serasah alang-alang pada tanaman sebelumnya dijadikan mulsa. Menurut Utomo (1994) pada sistem tanpa olah tanah memiliki kelembapan yang tinggi dan sistem perakaran yang baik akibat adanya mulsa sehingga dapat meningkatkan aktivitas mikroorganisme di dalam tanah. Selain itu, hal ini diduga dengan meningkatnya aktivitas mikroba tanah pada masa vegetatif maksimum berkaitan dengan ketersediaan Corganik yang tinggi sehingga mempengaruhi meningkatnya $\mathrm{CO}_{2}$ tanah dari eksudat akar, tambahan substrat dari jasad-jasad mikroorganisme yang telah mati sehingga dapat menjadi sumber energi dan nutrisi bagi mikroba tanah untuk beraktivitas dalam penyediaan unsur hara. Pemberian bahan organik dan sisa bahan organik tidak hanya berfungsi sebagai sumber hara melainkan dapat meningkatkan jumlah, keanekaragaman mikroorganisme serta aktivitas mikroorganisme dalam tanah (Albiach et al., 2000).

Sedangkan pada pengamatan satu hari sebelum panen tanaman kedelai, perlakuan olah tanah baik tanpa olah tanah (TOT), olah tanah minimum (OTM) dan olah tanah intensif (OTI) belum menunjukkan perbedaan yang signifikan terhadap total bakteri tanah. Hal ini diduga kandungan bahan organik dalam tanah telah berkurang karena digunakan untuk aktivitas mikroba tanah. Pengolahan tanah yang dilakukan secara terus menerus dapat menurunkan kandungan $\mathrm{C}$-organik dalam tanah, sehingga jumlah $\mathrm{C}$-organik yang berperan sebagai nutrisi bagi bakteri tanah akan cenderung menurun. Sistem tanpa olah tanah memiliki keunggulan yaitu tidak menyebabkan terganggunya $\mathrm{C}$-organik tanah, perubahan kandungan $\mathrm{C}$-organik ini merupakan sebagai akibat meningkatnya kombinasi antara laju dekomposisi bahan organik dan kurangnya gangguan terhadap tanah (Six et al., 1999).

Hasil uji korelasi (Tabel 3) menunjukkan bahwa terdapat korelasi negatif antara $\mathrm{pH}$ tanah dengan total bakteri tanah pada pengamatan satu hari sebelum panen tanaman kedelai. Artinya, meningkatnya $\mathrm{pH}$ tanah akan menurunkan total bakteri tanah. Dalam penelitian ini, $\mathrm{pH}$ rata-rata berkisar antara 5-5,5 (Tabel 4). Menurut Suriani et al., (2013) pengaruh $\mathrm{pH}$ terhadap pertumbuhan bakteri ini berkaitan dengan aktivitas enzim.

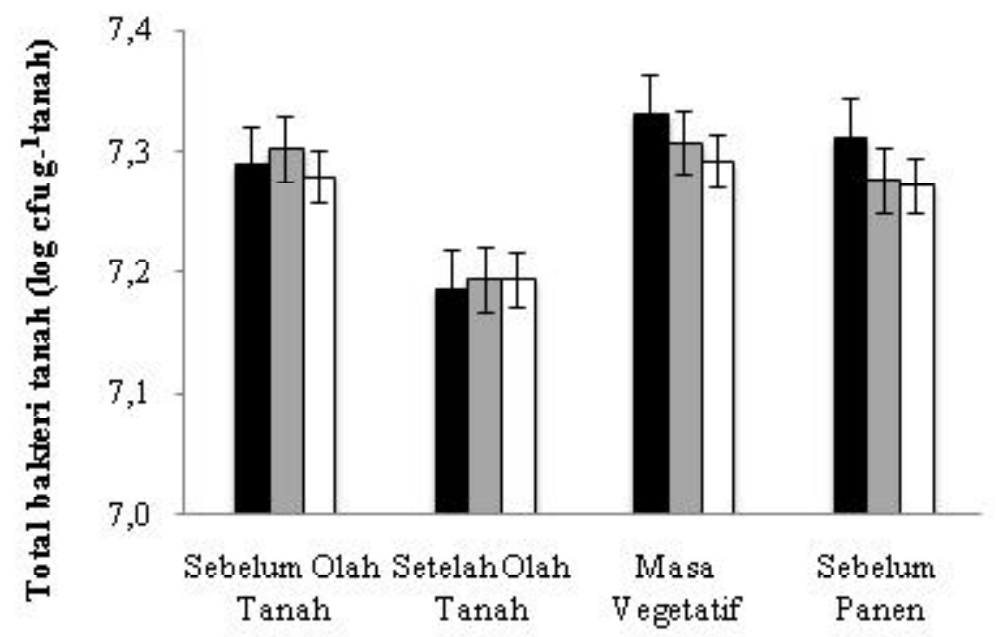

Gambar 1. Pengaruh perlakuan olah tanah pada lahan alang-alang terhadap perubahan total bakteri tanah yang ditanami kedelai pada pengamatan sebelum olah tanah, satu hari setelah olah tanah, masa vegetatif maksimum dan satu hari sebelum panen tanaman kedelai. Tongkat bar menunjukkan standar error pada taraf $5 \%$. $\bullet$ TOT, 口OTM, 口OTI. 
Tabel 3. Ringkasan hasil uji korelasi antara total bakteri tanah dengan $\mathrm{pH}, \mathrm{C}$-organik, N-total, suhu, dan kelembaban tanah

\begin{tabular}{|c|c|}
\hline Variabel & $\begin{array}{l}\text { Nilai } r \text { total bakt eri tanah } \\
\left.\text { ( } \log \text { CFU g } g^{-1} \text { tanah }\right)\end{array}$ \\
\hline pH tanah & $-0,61^{* *}$ \\
\hline C-organik & $-0,20^{\operatorname{tn}}$ \\
\hline N-total & $-0,13^{\text {tn }}$ \\
\hline Suhu & $-0,47^{\text {tn }}$ \\
\hline Kelembaban & $0,23^{\text {tn }}$ \\
\hline
\end{tabular}

Keterangan $: \mathrm{tn}=$ tidak berbeda nyata; $* *$ sangat nyata

Tabel 4. Pengaruh perlakuan olah tanah terhadap sifat tanah satu hari sebelum panen tanaman kedelai

\begin{tabular}{ccccccc}
\hline \multirow{2}{*}{ Perlakuan } & $\begin{array}{c}\mathrm{pH} \\
\left(\mathrm{H}_{2} \mathrm{O}\right)\end{array}$ & $\begin{array}{c}\text { C-Organik } \\
(\%)\end{array}$ & $\begin{array}{c}\text { N-Total } \\
(\%)\end{array}$ & $\begin{array}{c}\text { Suhu } \\
(\% \mathrm{C})\end{array}$ & $\begin{array}{c}\text { Kelembaban } \\
(\%)\end{array}$ & $\begin{array}{c}\text { Kadar Air } \\
(\%)\end{array}$ \\
\hline TOT & 5,2 & 1,2 & 0,66 & 29,2 & 49,3 & 21,5 \\
OTM & 5,5 & 1,2 & 0,71 & 29,3 & 48,0 & 20,1 \\
OTI & 5,4 & 1,2 & 0,64 & 29,3 & 46,7 & 20,0 \\
\hline
\end{tabular}

Keterangan: * Kelembaban (\%): diukur dengan menggunakan soil moisture tester $*$ Kadar air (\%): diukur dengan memperhitungkan berat kering tanah.

Enzim ini dibutuhkan oleh beberapa bakteri untuk mengkatalis reaksi reaksi yang berhubungan dengan pertumbuhan bakteri. Apabila $\mathrm{pH}$ dalam suatu medium atau lingkungan tidak optimal maka akan mengganggu kerja enzim enzim tersebut dan akhirnya mengganggu pertumbuhan bakteri itu sendiri.

Hasil uji korelasi (Tabel 3) menunjukkan tidak terdapat korelasi antara beberapa sifat kimia tanah lainnya seperti C-organik, N-total, suhu serta kelembapan tanahdengan total bakteri tanah pada pengamatan satu hari sebelum panen tanaman kedelai (Gambar 4, 5, 6, 7, Lampiran). Hal ini diduga perubahan sifat kimia tanah memerlukan waktu yang lama sehingga bahan organik belum terdekomposisi secara keseluruhan menjadi C-organik dan unsur hara yang lainnya karena singkatnya waktu penelitian yang digunakan.

\section{KESIMPULAN DAN SARAN}

\section{Kesimpulan}

Dari hasil dan pembahasan dapat disimpulkan sebagai berikut: (1) Perlakuan olah tanah baik sistem tanpa olah tanah (TOT), olah tanah minimum (OTM) maupun olah tanah intensif (OTI) tidak mempengaruhi total bakteri tanah pada pengamatan dua minggu sebelum olah tanah, satu hari setelah olah tanah, masa vegetatif maksimum dan satu hari sebelum panen tanaman kedelai. (2) Pada perlakuan olah tanah baik tanpa olah tanah (TOT), olah tanah minimum (OTM) maupun olah tanah intensif (OTI), total bakteri tanah menurun setelah dilakukan pengolahan tanah kemudian meningkat pada fase vegetatif maksimum dan tidak berbeda pada waktu sebelum panen. Tidak adanya perbedaan total bakteri tanah pada berbagai perlakuan olah tanah diduga berkaitan dengan tidak adanya perubahan yang signifikan pada beberapa sifat fisika dan kimia tanah. (3) Hasil uji korelasi menunjukkan bahwa terdapat korelasi negatif antara $\mathrm{pH}$ tanah $\left(\mathrm{H}_{2} \mathrm{O}\right)$ dengan total bakteri tanah. Sedangkan uji korelasi beberapa sifat kimia tanah lainnya seperti C-organik, N-total, suhu, serta kelembapan tanah menunjukkan bahwa tidak terdapat korelasi dengan total bakteri tanah.

\section{Saran}

Penelitian ini sebaiknya dilanjutkan pada musim tanam berikutnya untuk melihat perbedaan total bakteri tanah dengan perlakuan olah tanah dalam jangka panjang. 


\section{DAFTAR PUSTAKA}

Albiach, R., R. Canet, F. Pomares, and F. Ingelmo. 2000. Microbiomass content and enzymatic after the application of organic amendments to a horticultural. Soil. Bior. Teach. 75: 43-48.

Anas, I. 1989. Biologi Tanah dalam Praktek. Departemen Pendidikan dan Kebudayaan Direktorat Jendral Pendidikan Tinggi Pusat antar Universitas Bioteknologi. Institut Pertanian Bogor. $161 \mathrm{hlm}$.

Arif, M. A. S., A. Niswati, S. Yusnaini, Dermiyati, dan S. G. Nugroho. 2009. Biologi Tanah. Penuntun Praktikum. Fakultas Pertanian. Universitas Lampung. Bandar Lampung. $19 \mathrm{hlm}$.
Six.J.,E.T Elliot., and K. Paustian. 1999. Aggregate and soil organic matter dynamics under conventional and no-tillage systems. Soil Sci. Soc. Am. J.63:1350-1358.

Suriani, S., Soemarno, dan Suharjono. 2013.Pengaruh Suhu dan $\mathrm{pH}$ terhadap Laju pertumbuhan Lima Isolat Bakteri Anggota Genus Pseudomonas yang diisolasi dari Ekosistem Sungai Tercemar Deterjen disekitar Kampus Universitas Brawijaya. J. PAL.Vol. $3.5 \mathrm{hlm}$.

Utomo, M. 1994. Peran Olah Tanah Konservasi dalam Pengelolaan Tanah Berwawasan Lingkungan di Lahan Kering. Disajikan dalam rapat teknis perencanaan/sinkronisasi program dan proyek proyek pembangunan tanaman pangan dan hortikultura tingkat Nasional, 1995/1994, Bandar Lampung 24-28 Oktober 1994. 